بررسى دقت تخمين پارامترهاى معادله نفوذ بر اساس ويزُگىهاى فيزيكى خاك در آبيارى جويجهاى

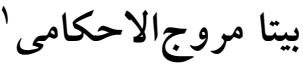

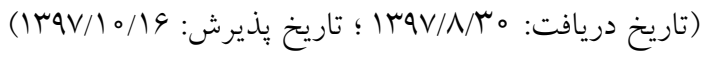

جكيده

آبيارى جو يجهاى يكى از معمولترين روشهاى آبيارى سطحى است. با اين وجوده، تخمين دقيق معادله نفوذ آب به خـاك، مهـم تـرين

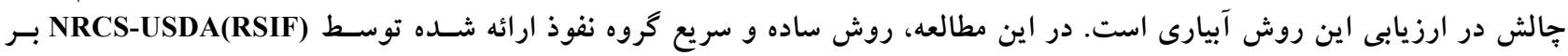

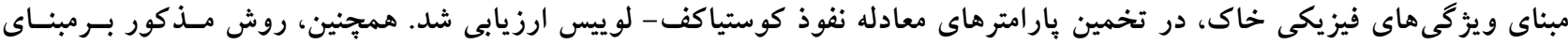

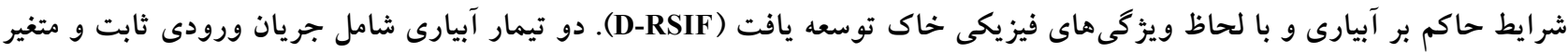

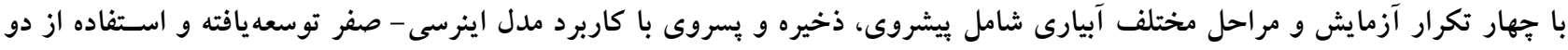

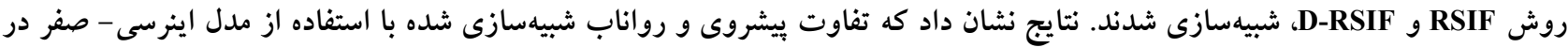

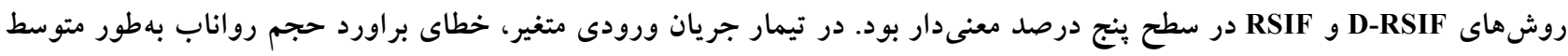

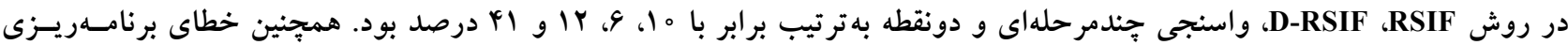

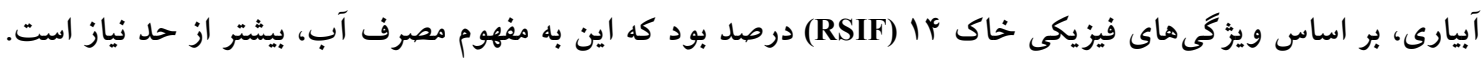

وازههاى كليدى: نفوذ، ويزّى هاى فيزيكى خاك، آبيارى جويجهاى، مدل اينرسى -صفر

1. بخش خاك و آب مركز تحقيقات و آموزش كشاورزى و منابع طبيعى استان يزد، سازمان تحقيقات، آموزش و ترويج كشاورزى، يزد، ايران

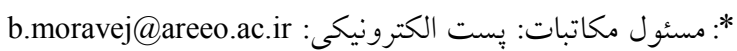


آبيـارى تأكيـده شــده اسـت كـه منجــر بـهـ افـز ايش دقـت بــراورد

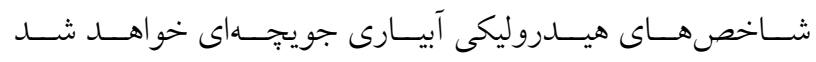

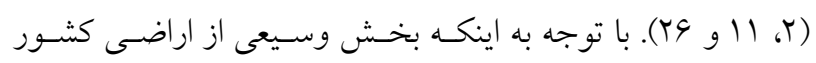

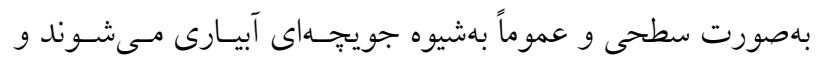

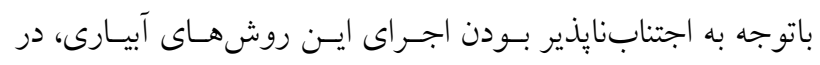

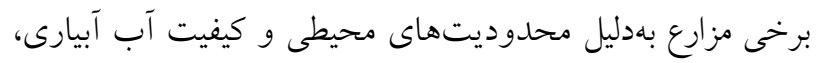
ضرورت دارد نسبت به بهبود برنامهريزى و مديريت دقيـق ايسن

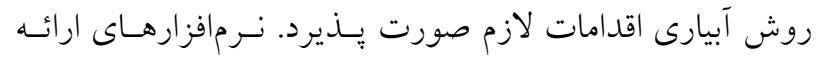

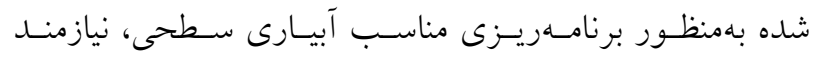

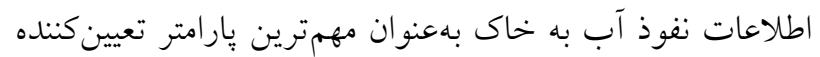

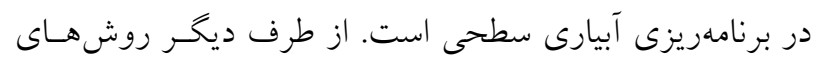

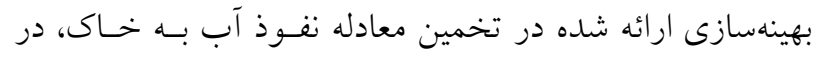

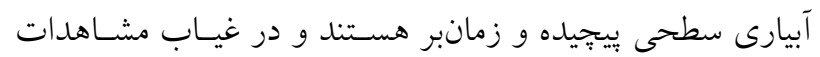

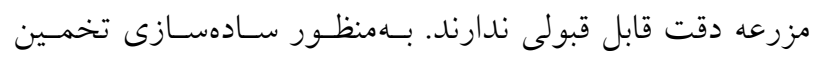

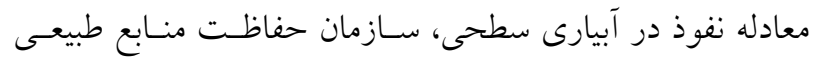

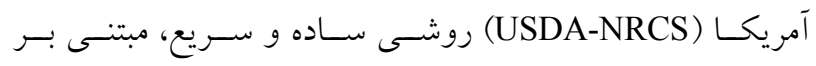

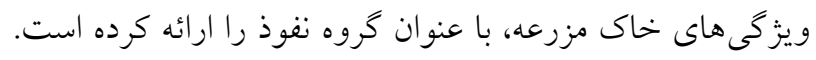

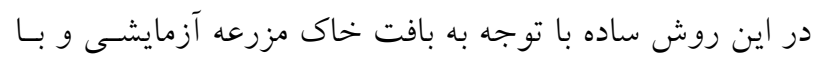

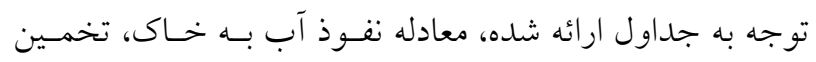

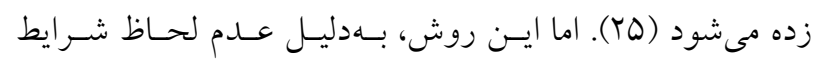

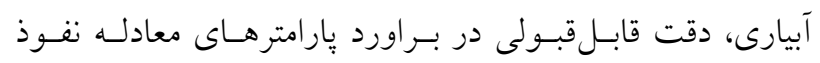

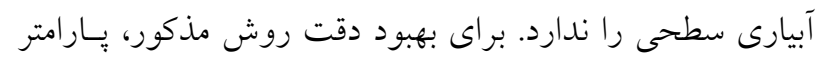

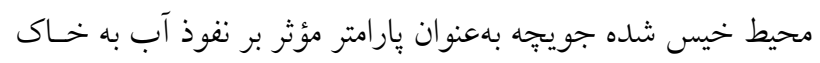

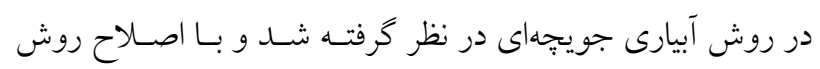
مذكور، روش گروه نفوذ اصلاح شده (كه در اين مطالعه به اختصار

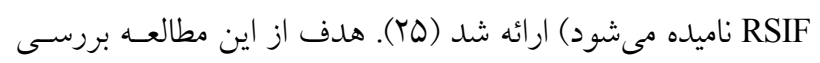

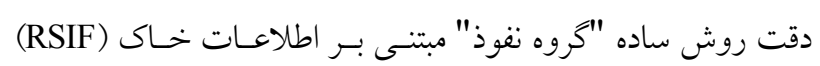

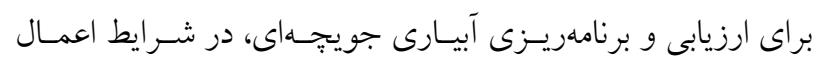

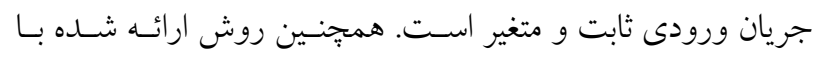
لحاظ هيدروليك جريان شامل دادههاى بيشروى (بـهنظـور لحساظ فاز بيشروى)، حجم رواناب و دادههاى بِروى (بدمنظور لحاظ فـاز بسروى و ذخيره) توسعه و مورد ارزيابى قرار كرفت (D-RSIF).
آبيارى جويجهاى بهدليل كاربرد آن در خسـتره وسـيعى از انسواع

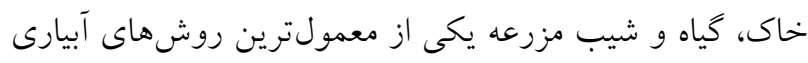

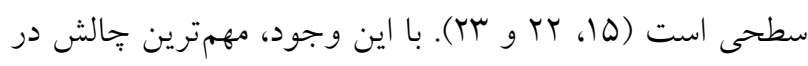
طراحى و ارزيابى آبيارى جويجهاى، تخمين هرجه دقيق معادلـه

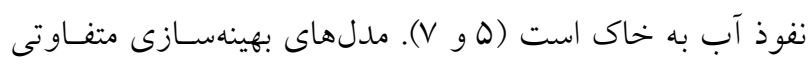

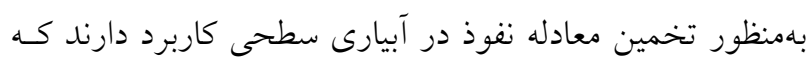

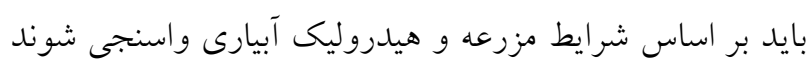

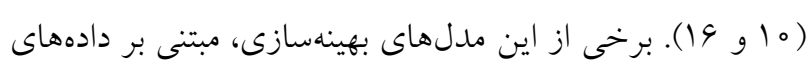

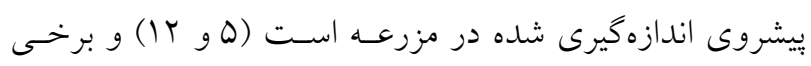

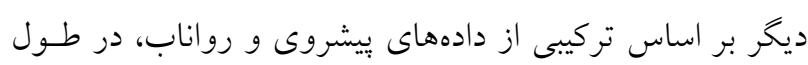

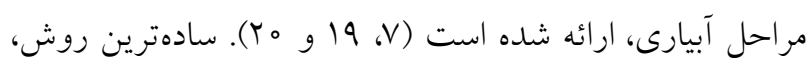

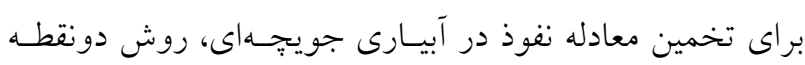

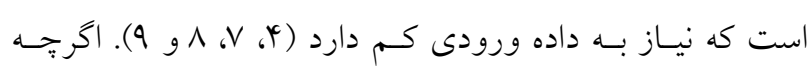

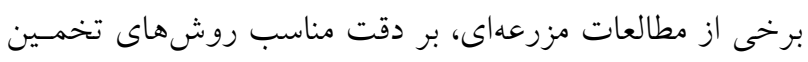

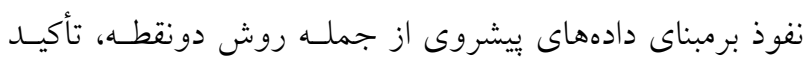

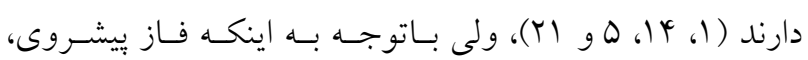

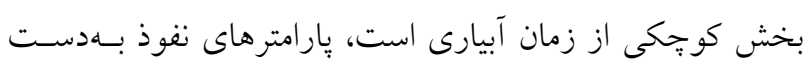

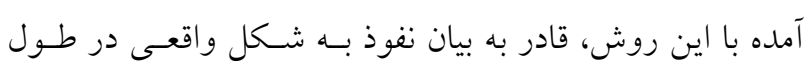

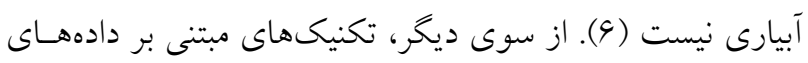

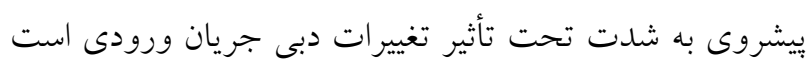

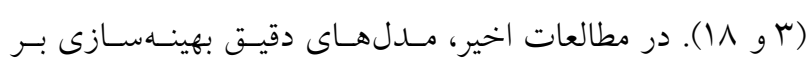

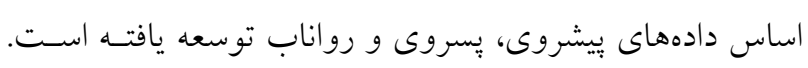

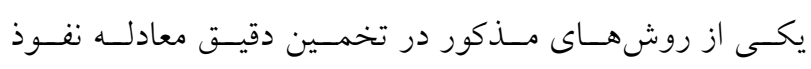

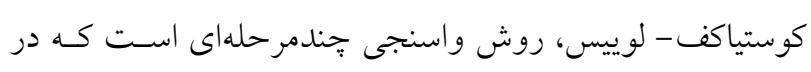

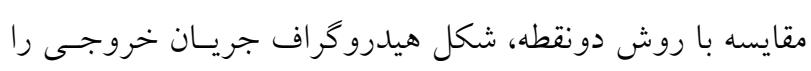

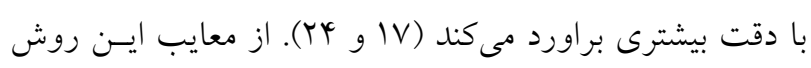

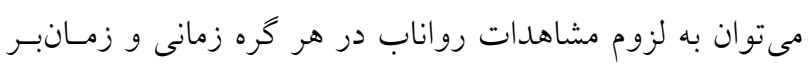

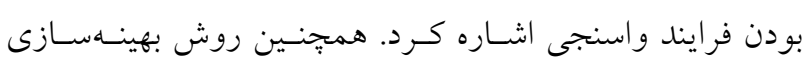

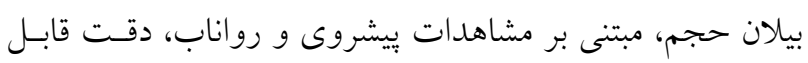

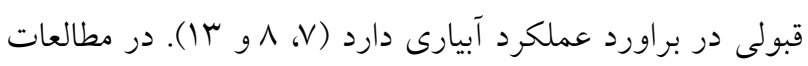

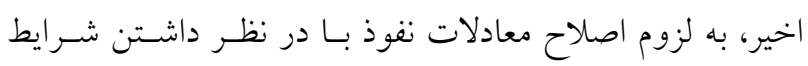


در اين مطالعه بـهـنظـور لحـاظ هيـدروليك آبيـارى در كنـار

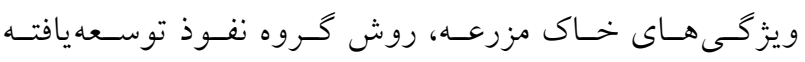

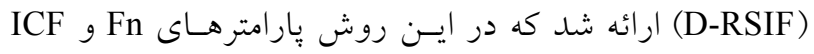
براساس مشاهدات مزرعه واسنجى شدند. در ابتدا شماره كروه

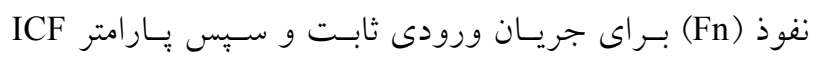
بهمنظور لحاظ تغييرات جريـان ورودى بـر اسـاس مشـاهدات

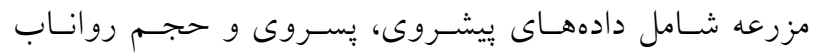

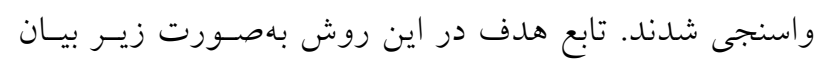
objectivefunction $=\left(\mathrm{Vr}_{\mathrm{o}}-\mathrm{Vr}_{\mathrm{m}}\right)$

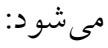
كه در اين رابطه Vro: حجم رواناب مشاهده شده و Vrm: حجـم رواناب تخمين زده شده است. همجنين مدل اينرسى- صفر بهمنظور شبيهسازى مراحـل

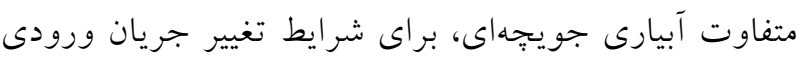
توسعه يافت. در اين مدل از روش حجم كنترل تغييريـذير و

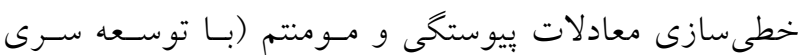

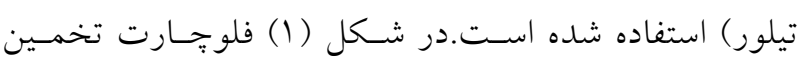
معادله نفوذ بهروش گروه نفوذ توسعه يافته ارائه شده است.

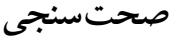

بهمنظور صحتسنجى روش گـــروه نفـوذ توسـعليافتـه در ايسن

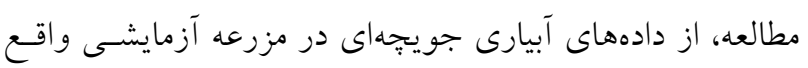
در دانشكاه صنعتى اصفهان (بr درجه و FV دقيقه شـمالى و اله

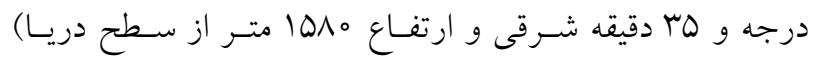

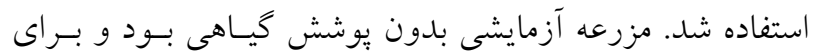

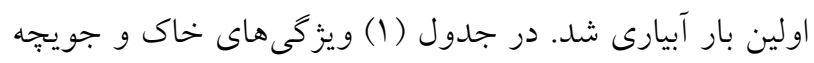

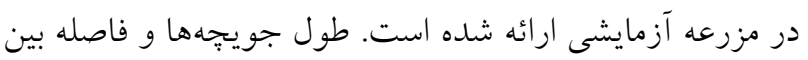

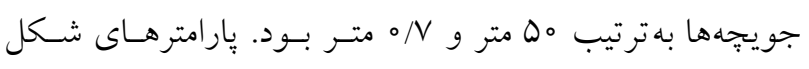

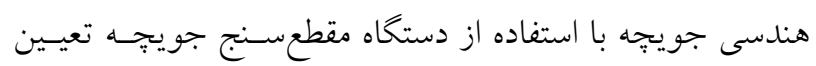

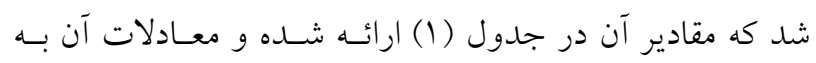

$$
\mathrm{A}=\sigma_{\imath} \mathrm{y}^{\sigma_{r}}
$$

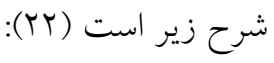

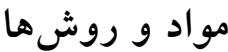

روش گروه نفوذ (RSIF) و روش گروه نفوذ توسعهيافته (D-RSIF)

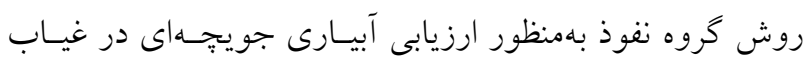

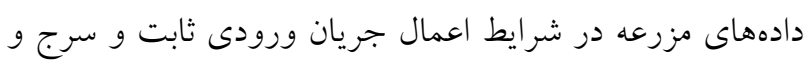

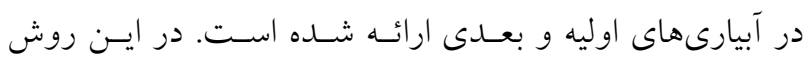

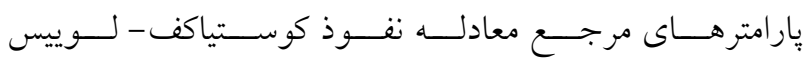
با استفاده از شـماره خـروه نفـوذ ارائسه شــده (Fn) بهصورت زير بيان مىشوند (Tه):

$$
\mathrm{Z}=\mathrm{Kt}^{\mathrm{a}}+\mathrm{f}_{\mathrm{o}} \mathrm{t}
$$

$a_{\text {ref }}=\frac{0 / 10 V 1+r / 0 V r q \times F n}{1+r / 9 q 40 \times F n-0 / 114 q \times F^{r}}$

$\mathrm{K}_{\text {ref }}=0 / 00 \operatorname{TrV}(\mathrm{Fn}+0 / 00 \mu 19)^{\circ / 0 \Lambda I V}$

$\mathrm{f}_{\text {oref }}=0 / 0004 \Delta 4\left(1 / 0149-\mathrm{e}^{(-0 / 0099 \times \mathrm{Fn})}\right)$

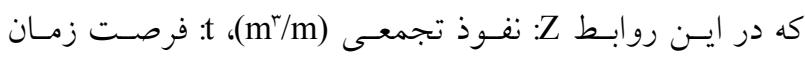

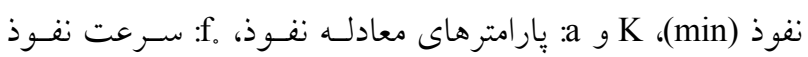

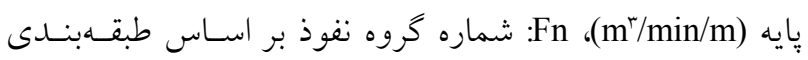

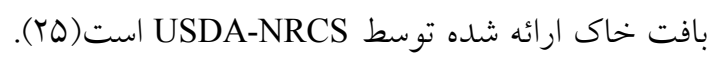
دبى جريان ورودى مرجع (Qref) با توجه بـه شـماره خـروه نفوذ بهصورت زير ارائه مىشود:

$\mathrm{Q}_{\text {ref }}=0 / \mathrm{rrr}^{\mathrm{r}}+1 / \mathrm{Vq} \times \mathrm{Fn}-0 / \mathrm{rQ} \boldsymbol{\mathrm { F }} \times \mathrm{Fn}^{r}$

براى تعديل بارامترهاى نفوذ، WPref (محيط خيس شده مرجـع) بهصورت زير محاسبه مىشود:

WP $P_{\text {ref }}=0 / r 9 \Lambda \times(\mathrm{Fn}-0 / 1 \% \mathrm{rV})^{\circ / \Delta r \wedge}$

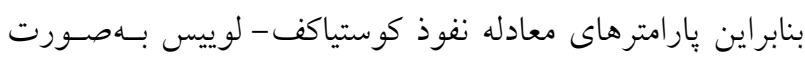

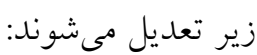

$\mathrm{a}=\mathrm{ICF} \times \mathrm{a}_{\mathrm{ref}}$

$\mathrm{K}=\mathrm{ICF} \times \mathrm{K}_{\text {ref }} \times\left[\frac{\mathrm{WP} \mathrm{P}_{\mathrm{a}}}{\mathrm{W} \mathrm{p}_{\text {ref }}}\right]$
$\mathrm{f}_{\mathrm{o}}=\mathrm{ICF} \times \mathrm{f}_{0 \text { ref }} \times\left[\frac{\mathrm{WP} \mathrm{P}_{\mathrm{a}}}{\mathrm{W} \mathrm{p}_{\text {ref }}}\right]$

كه در اين روابط ICF: فـاكتور شـرايط آبيـارى و WPa: محسيط خيس شده جويتجه تعيين شده در مزرعه است. 


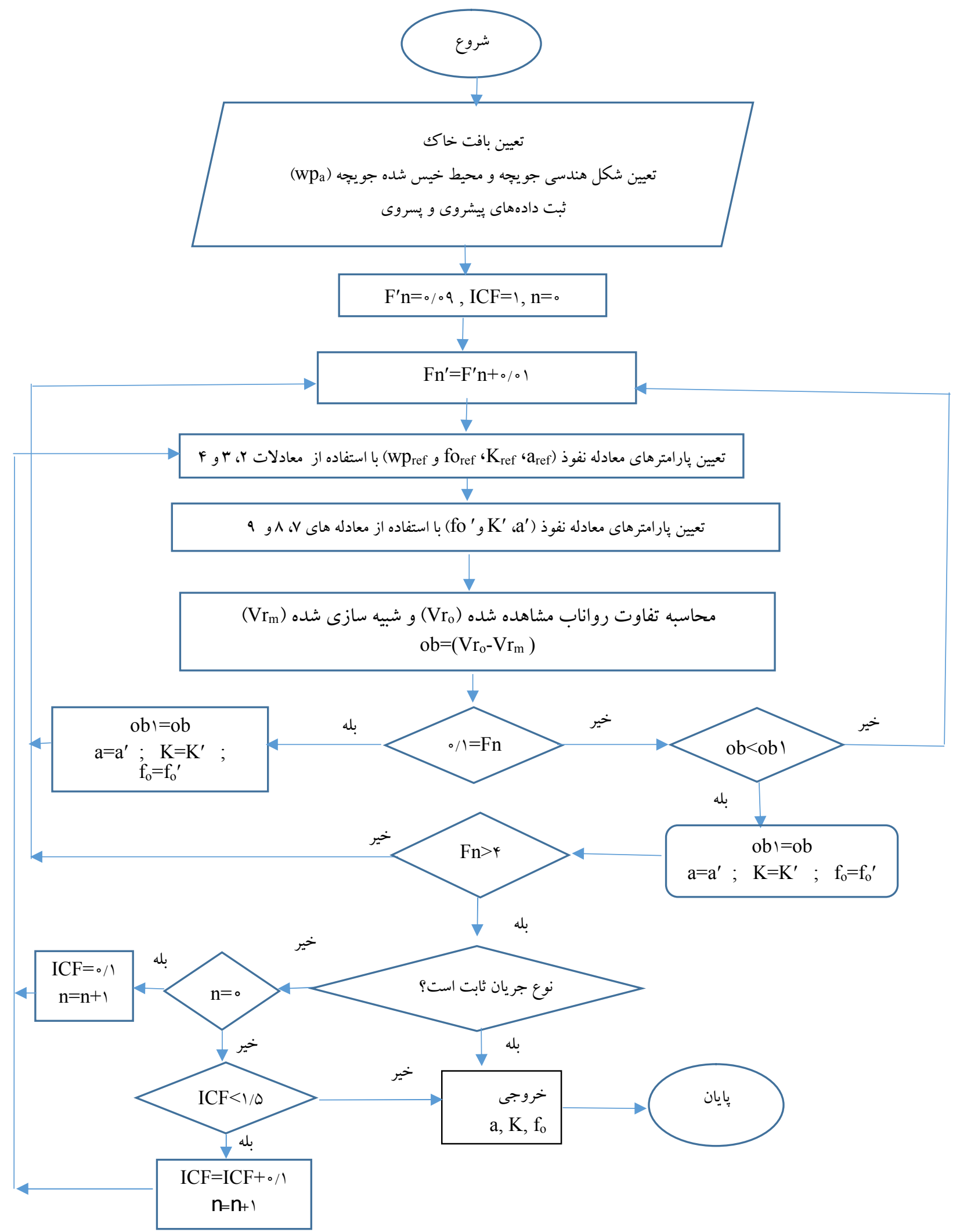

شكل ا. نمايى از تخمين معادله نفوذ به روش D-RSIF براى جريان ورودى ثابت و متغير 
جدول ا. ويزگگىهاى مزرعه آزمايشى براى صحتسنجى روش گروه نفوذ توسعه يافته (D-RSIF)

\begin{tabular}{|c|c|c|c|c|c|c|c|c|}
\hline \multicolumn{2}{|c|}{ محيط خيس شده جويجهه } & \multicolumn{2}{|c|}{ سطح هندسى جويجهن } & \multirow{2}{*}{ بافت خاك } & \multirow{2}{*}{ شيب مزرعه } & \multirow{2}{*}{ خاك ( دانسيته ظاهرى } & \multirow{2}{*}{ طولجويجه } & \multirow{2}{*}{ رطوبت اوليه خاى } \\
\hline$\gamma_{r}$ & $\gamma_{1}$ & $\sigma_{r}$ & $\sigma_{1}$ & & & & & \\
\hline.$/ 09$ & $1 / 19$ & $1 / 4 \circ \Lambda$ & $\circ / \mathrm{VV}$ & ل لوم شنى & $\circ / \circ \circ \Delta$ & $1 / T 4$ & Q. & $V / \uparrow Q$ \\
\hline
\end{tabular}

(ب)

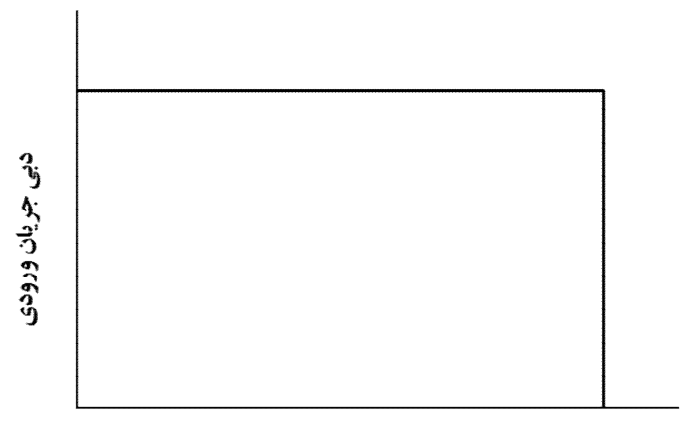

زمان

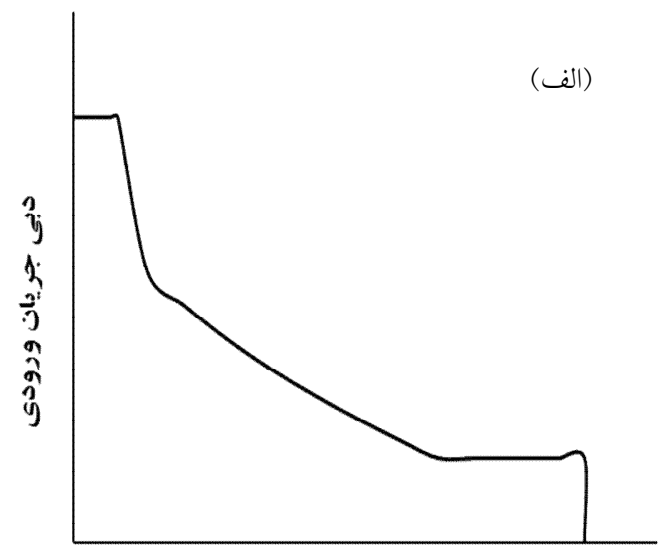

زمان

شكل r. نمايى از الخوى جريان آب ورودى به جويجههاى آزمايشى: الف) تيمار جريان ورودى ثابت و ب) تيمار جريان ورودى متغير

ايستخاهبندى شدند و زمـانهـاى يِيشـروى و بـــروى در هـر

ايستخاه در طول جويجه ثبت شد. جريان ورودى به جويجٍه و جريان خروجسى از جويجيهـ در تيمارهـاى مـورد آزمـايش بـا

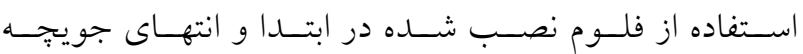

$$
\text { اندازه گيرى شد. }
$$

مقايسه روش گروه نفوذ با روش واسـنجى جندمرحلـهاى و روش دونقطه

بهمنظـور بررسـى دقـت روش خـروه نفـوذ ارائهه شـده توسط USDA-NRCS اين روشها از نظر دقت و سادكى اجرا با روش دقيق واسـنجى جندمرحلهاى و روش ساده دونقطه مقايسه شدند.

$$
\text { روش واسنجى جندمرحلهاى }
$$

يكى از روشهـاى دقيـق بــراورد نقــوذ آب بـه خــاى در آبيـارى

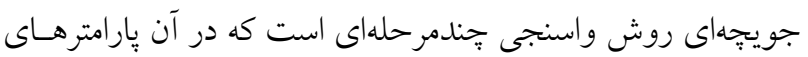

كه در اين روابط y: عمق آب (m)، Aطح مقطع هندسى جويجه: (WP (mr) تجربى است. تيمارهاى آزمايشى شامل جريـان ورودى ثابـت بـا جهـار تكرار و جريان ورودى متغير با جهار تكرار بود. در هر يك از تيمارهاى مورد آزمايش، يك تكرار براى واسنجى يارامترهـاى معادله نفوذ كوستياكف- لوييس و سه تكــرار ديخـر بـهنظــور صحتسنجى روش مذكور استفاده شد. در تيمار جريان ثابت،

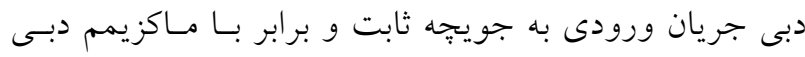
غيرفرسايشى بود. در تيمار جريان ورودى متغير، دبسى جريـان

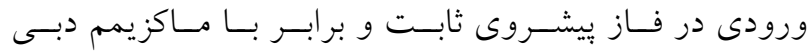
غيرفرسايشى بود و بعد از تكميل فاز بيشـروى بــا اسـتفاده از شير كنترل اتوماتيك طراحى شده بهصـورت تـدريجى كـاهش يافت (شكل r). حجم آب كاربردى براى تيمارهاى آزمايشى يكسـان در نظـر كرفتسه شـــ. جويتجـهـهـاى مـورد آزمـايش 
مقطع متوسط در زمان to است. است.

نتايج

مقايسه روش گروه نفوذ توسعهيافته(D-RSIF) و روش گروه

USDA-NRCS (RSIF) نفوذ ارائه شده توسط

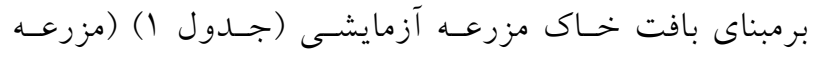

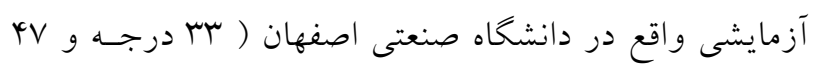

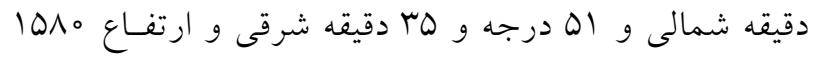
متر از سطح دريا)، شماره گروه نفـوذ (Fn)، در روش گـروه نفوذ (RSIF) براسـاس جـداول USDA-NRCS، 9 / اسـت (TO) (TO) در روش كروه نفوذ توسعهيافته، پارامتر Fn با استفاده

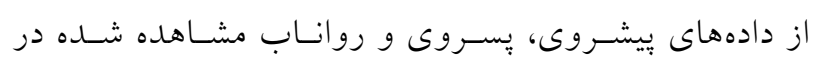
مزرعه و با استفاده از تابع هدف (معادله ه ا) واسـنجى شـد. بارامتر ICF (فاكتور شـرايط آبيـارى) متـأثر از دبسى جريـان ورودى به جويجه است، لذا اين پيارامتر براى تيمـار جريـان

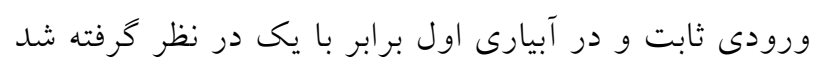

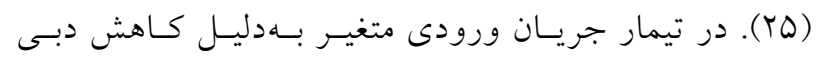
جريان ورودى بعد از تكميل فاز بيشــروى از يـك طـرف و تأثير تغييرات دبى جريــان ورودى بــر نفـوذ از طـرف ديخـر،

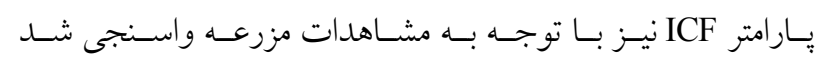

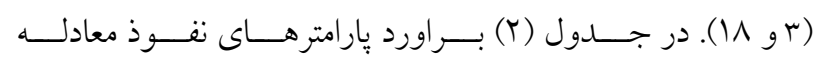
كوستياكف -لوييس با اسـتفاده از دو روش RSIF و D-RSIF ارائسه شده است. باتوجه به اينكه روش RSIF مبتنى بر ويزگى هاى

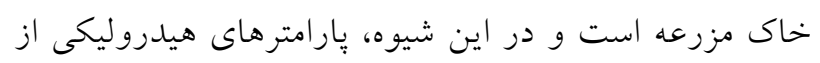
جمله، تغيير جريان ورودى به جويتجه لحاظ نمىشـود، يارامترهـاى معادلـه نفـوذ تخمينسى بــا ايسـن روش در مزرعـهـ آزمايشـى، بــراى دو تيمار جريان ورودى ثابت و متغير باتوجه به بافت خـاك مزرعـه آزمايشى يكسان لحساظ شـده اسـت. امـا در روش D-RSIF بهدليل تخمين بِارامترهـاى معادلـه نفـوذ كوسـياكف -لـوييس برمبناى ويزگى هاى خاك و لحاظ تغييـرات جريـان آب ورودى بـه

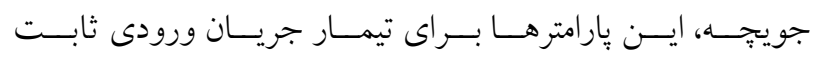

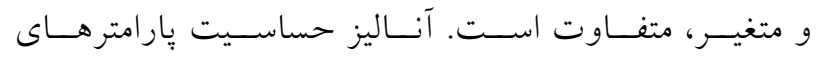

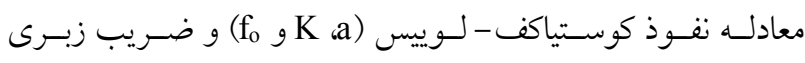
مانينخ بر اساس مشاهدات مزرعه واسنجى مىشوند (YY). مراحل واسنجى به روش مذكور بهشرح زير است: مرحله اول: تعيين K بهينه با مقادير فرض شـده اوليـهـ a a

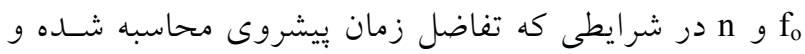
مشاهده شده در انتهاى جويتجه حسـداقل بـاشــ، مرحلـه دوم:

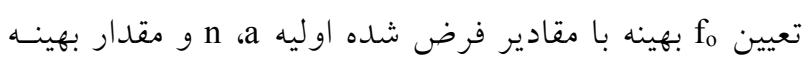
L در مرحله اول، در شرايطى كه ريشه تفاضل مربعات براى مقادير مشاهده شده و محاسبه شده رواناب در هـر نقطـه از زمان حداقل باشد، مرحله سـوم: تعيـين a بهينــه بـا اسـتفاده ازمقدار فرض اوليه n و مقادير بهينه شده k و ffo در شرايطى كـه ريشـه تفاضـل مربعـات بــراى مقـادير مشــاهده شـده و محاسبه شده رواناب در هر نقطـه از زمـان حــداقل باشـد و مرحله جهارم: تعيين n بهينه با استفاده از مقادير بهينسه شـده fo g a a و مشاهده شده تا انتهاى جويجهه حداقل باشد (YY).

\section{روش دونقطه}

روش دونقطه بر اساس كاربرد معادله بيلان حجم و بعد از انجام آزمايشهــاى متعـدد نفــوذ، بـا اسـتفاده از دادههـاى مزرعـه در

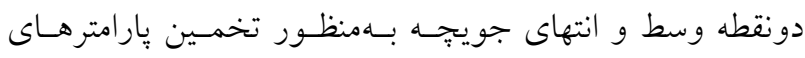
معادله نفوذ كوستياكف ارائه شده است. معادلات ارائه شده براى دو نقطه مذكور به شرح زير است (YT):

$$
\begin{aligned}
& V_{L}=\left(\frac{Q_{0} t_{L}}{L}-\bar{A}_{1}-\frac{f_{0} t_{L}}{1+r}\right) \\
& V_{\circ / \Delta L}=\left(\frac{r Q_{0} t_{o / \Delta L}}{L}-\bar{A}_{r}-\frac{f_{0} t_{o / \Delta L}}{1+r}\right)
\end{aligned}
$$

كه در اين روابط VL حجم آب ورودى به جويجهه در زمان رسيدن آب به انتهاى جويجِه، Qo : دبى جريان ورودى به جويجه، tL: زمـان يشيروى آب به انتهاى جويجيه، L: طول جويجــ،،

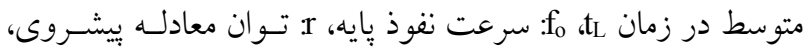
Vo/dL

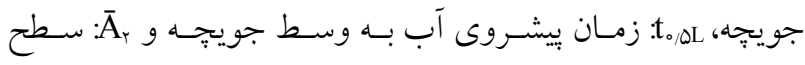


جدول Y. بارامترهاى نفوذ كوستياكف لوييس تخمينى با روش D-RSIF و RSIF

\begin{tabular}{|c|c|c|c|c|}
\hline fo & a & $\mathrm{K}$ & روش تخمين & تيمار \\
\hline ०/०००ץ & $\circ / 4 \wedge$ & $\circ / 0 \circ Y^{k}$ & D-RSIF & جريان ورودى \\
\hline \%०००द & $\circ / \Delta \Lambda$ & $\% \circ 40$ & RSIF & ثابت \\
\hline \%०004 & $\circ / \mathrm{QV}$ & $\circ / \circ \circ \Delta Y$ & D-RSIF & جريان ورودى \\
\hline \% /000मG & $\circ / 0 \Lambda$ & $\circ / \circ \circ 4$ & RSIF & متغير \\
\hline
\end{tabular}

جدول r. ارزيابى حجم نفوذ با روش D-RSIF و روش RSIF با استفاده از مدل اينرسى -صفر

\begin{tabular}{|c|c|c|c|c|c|c|}
\hline \multicolumn{2}{|c|}{$\overline{\mathrm{RSIF}}$} & \multicolumn{2}{|c|}{ D-RSIF } & \multirow{2}{*}{$\begin{array}{c}\text { مشاهده مزرعه } \\
\left(m^{r}\right)\end{array}$} & \multirow{2}{*}{ شماره جويتجه } & \multirow[t]{2}{*}{ تيمار } \\
\hline خطاى نسبى (\%) & شبيهسازى مدل & خطاى نسبى (\%) & شبيهسازى مدل & & & \\
\hline 荭 & $r / r V$ & $\mathrm{~V} / \mathrm{r}$ & $T / T V$ & $T / Y Q D$ & 1 & جريان ورودى ثابت \\
\hline$\Delta \circ / V$ & $r / 01$ & $\Delta / r$ & $T / 1$ & $1 / 99$ & r & \\
\hline$I V / T \wedge$ & $\varphi / 0$ & $9 / 9$ & $r / 9 T$ & $D / 4 Y^{4}$ & 1 & جريان ورودىى متغير \\
\hline$r 0 / 91$ & $p / 4 q$ & $1 \pi / 4$ & $\varphi / \Lambda$ & Q/D & r & \\
\hline
\end{tabular}

آب نفوذيافته شبيهسازى شده با مدل اينرسى -صفر توسـعهيافتـه و با كاربرد دو روش D-RSIF و RSIF ارائه شده است. با توجه به اين جدول، دقت روش D-RSIF در براورد حجم نفوذ نسبت به روش RSIF بيشتر است كه اين بهعلت لحاظ شرايط آبيـارى شامل بيشروى، يسروى و رواناب در تخمين بارامترهاى معادلـه

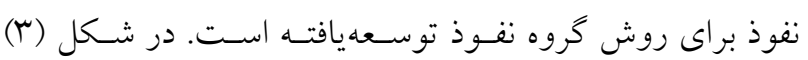
ييشروى شبيهسازى شده با استفاده از مــل اينرسىى -صـفر بـا

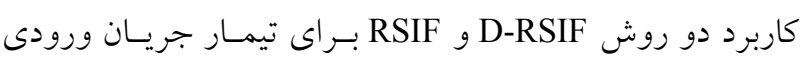
ثابت و متغير ارائه شده است. نتايج آنـاليز آمـارى بـا نــرمافـزار نشـان داد كـه تفـاوت دو روش در سـطح يـنج درصــ SPSS معنى دار است. با توجه به شكل (r) زمان يِيشروى بـراى تيمـار

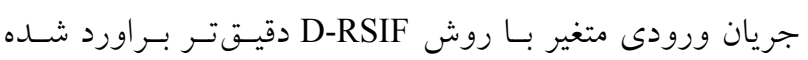

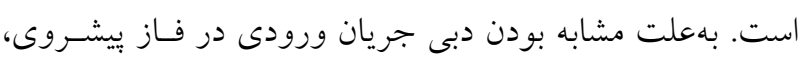
براى تيمارهاى جريان ورودى ثابت و متغيسر، تفـاوت دو روش RSIF در براورد بيشـروى در هـر دو تيمـار تقريبـاً يكسان است. در شكل (†) هيدرو گر اف رواناب شبيهسازى شده با استفاده از مدل اينرسى- صفر و با كـاربرد دو روش D-RSIF

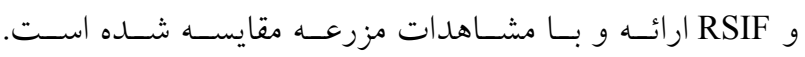
با توجه به اين شـكل تفـاوت بـين دو روش از نظـر آمـارى در

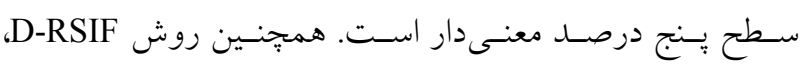

f و a foار امترهاى معادله نفوذ كوستياكف- لوييس) نشـان داده است كه اين پيارامترها بيشـتر تحست تـأثير روانـاب خروجسى از جويجه هستند و بهعبارتى مبين شرايط آبيارى در فـاز ذخيــهـو و يسروى هستند (YY). باتوجه به اينكه در تيمـار جريـان ورودى متغير، دبى جريان ورودى بعد از فاز بيشروى كاهش مىيابد لذا در مقايسه بـا تيمـار جريـان ورودى ثابـت، تـأثير دبسى جريـان ورودى بر نفوذ نسبت به تأثير ويزگى هاى فيزيكى خـاى كمتـر

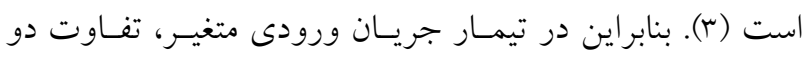
روش RSIF و D-RSIF در براورد يارامترهـاى a و f معنسى نيست (شكل Y ). بر اساس نتايج آناليز حساسـيت انجـام شـده،

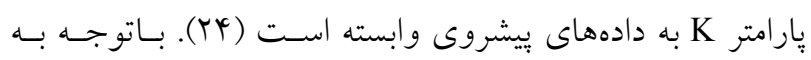
جدول (Y) پيـارامتر K تعيسين شــده بـا روش (D-RSIF) در دو تيمار جريـان ورودى ثابـت و متغيـر تقريبـاً يكسـان اسـت كـهـ

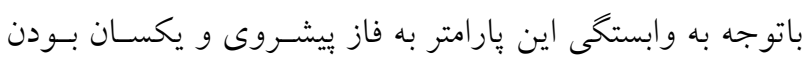

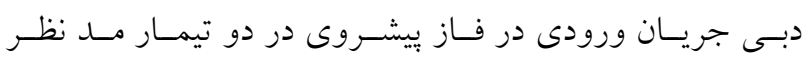

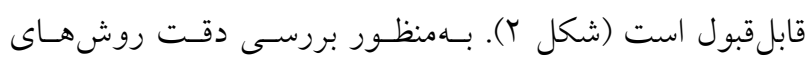
كروه نفوذ D-RSIF و RSIF، در تخمين بارامترهاى معادله نفوذ

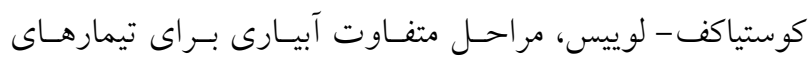

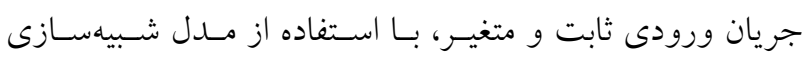
اينرسى- صفر توسعهيافته، شبيهازى شد. در جدول (ب)، حجم 
الف
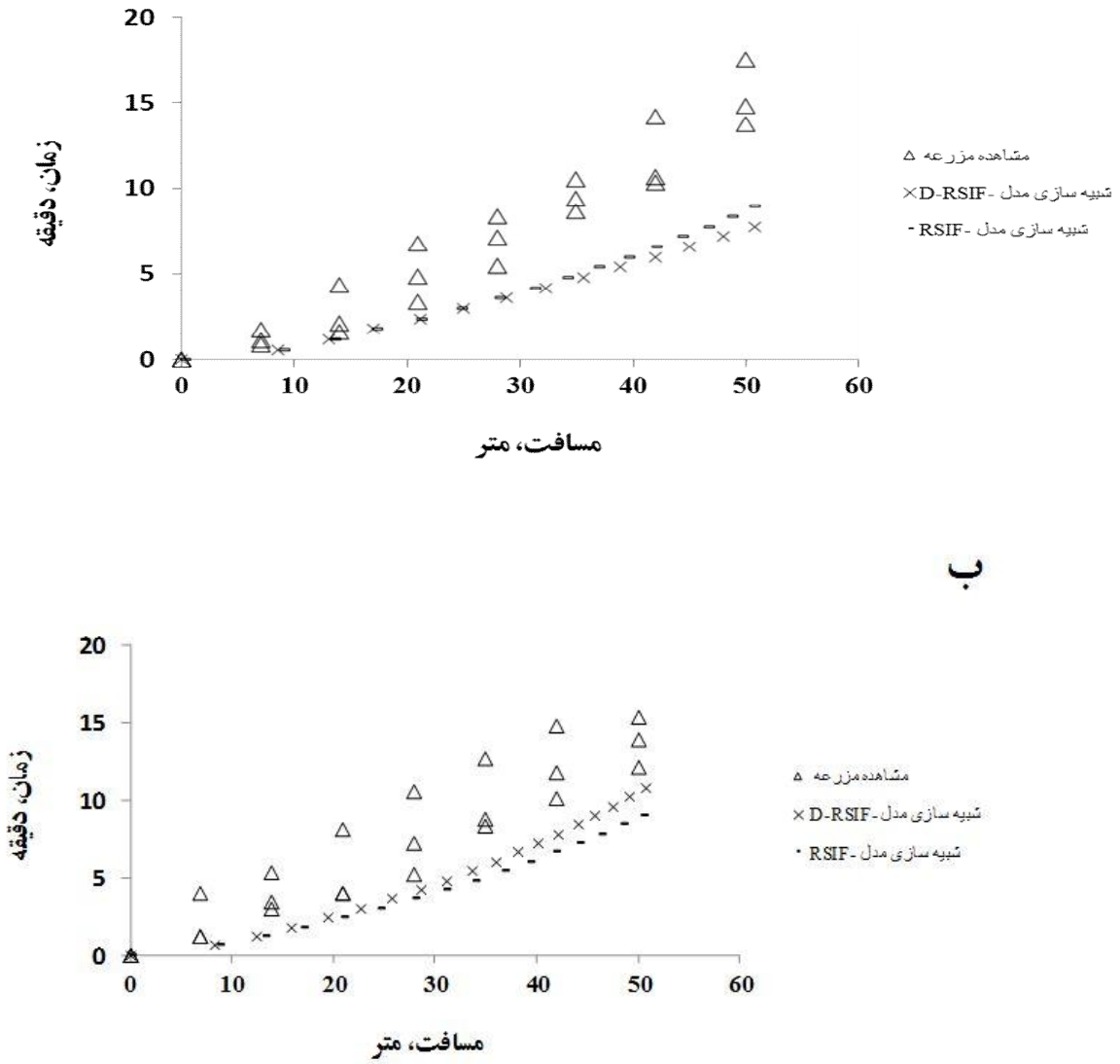

شكل r. زمان بيشروى شبيهسازى شده با مدل اينرسى -صفر با استفاده از روش D-RSIF و RSIF الف)تيمار جريان ورودى ثابت و ب) تيمار جريان ورودى متغير

روش بــراورد روانـاب، روش واسـنجى جندمر حلـهاى اسـت و دقت دو روش D-RSIF و دونقطه در براورد حجم روانـاب، در

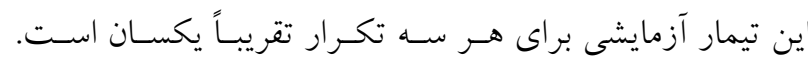
كمترين دقت در براورد حجم رواناب، در تيمار جريـان ورودى ثابت مربوط به روش RSIF مبتنى بر اطلاعات خاك اسـت كـه

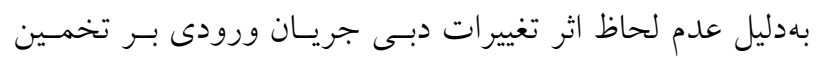

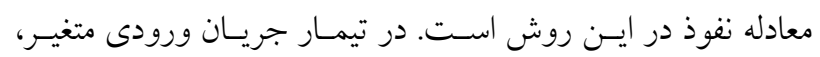

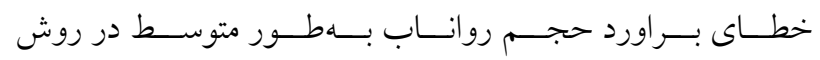

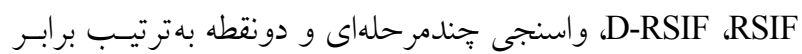
با •ا، 9، باو ال| درصد اسـت. در تيمـار جريـان ورودى متغيـر دقـت روش گــروه نقــوذ (DSIF) و R-RSIF) در بــراورد حجــم رواناب بيشتر از روش دقيق واسنجى جندمرحلهاى است.
شكل هيدرو گراف رواناب را با دقت بيشـترى بــراورد مسىكنـد. در

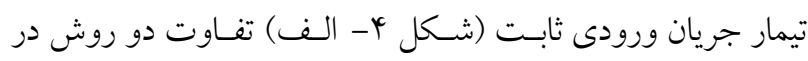
براورد هيـدروگر اف روانـاب، بيشـتر از تيمارجريـان ورودى متغيـر

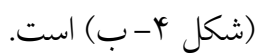

مقايسه روش گروه نفوذ و ساير روشهـاى تخمسين معادلـه نفوذ كوستياكف- لوييس در اين مطالعه، روش گروه نفوذ و روش گروه نفوذ توسعهيافتـه

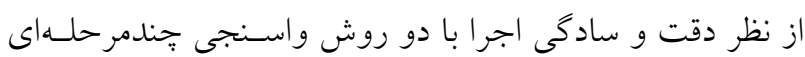

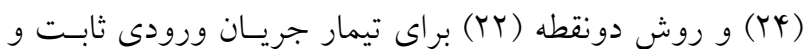
متغير مقايسه شد كه نتايج آن در جدول (Y) ارائه شده است. بـا توجه به جدول (†) در تيمار جريان ورودى ثابـت، دقيـقتـرين 

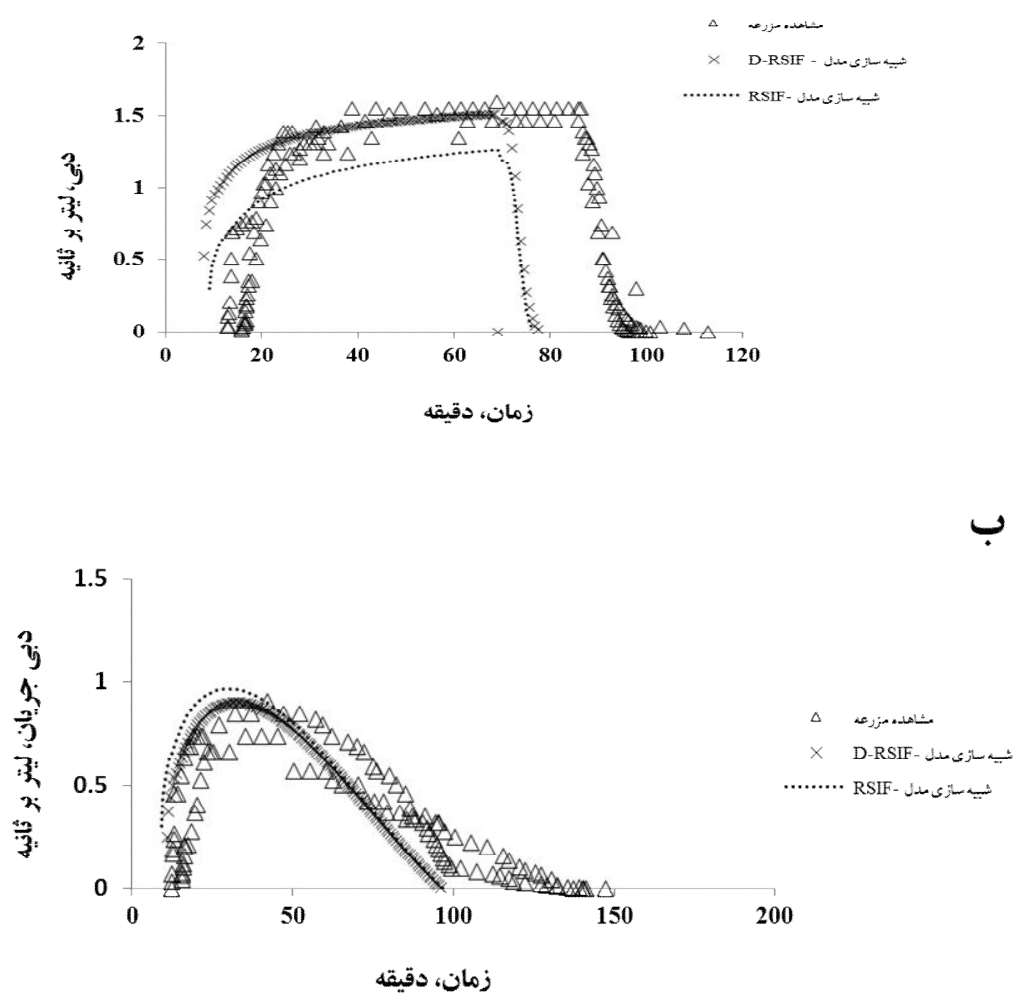

شكل أ. هيدرو گراف رواناب شبيهسازى شده بهوسيله مدل اينرسى -صفر با كاربرد روش D-RSIF و RSIF الف تيمار جريان ورودى ثابت و ب) تيمار جريان ورودى متغير

جدول F. حجم رواناب شبيهسازى شده با مدل اينرسى صفر باستفاده از روش DSSIF .RSF، روش واسنجى جندمرحلهاى و روش دونقطه

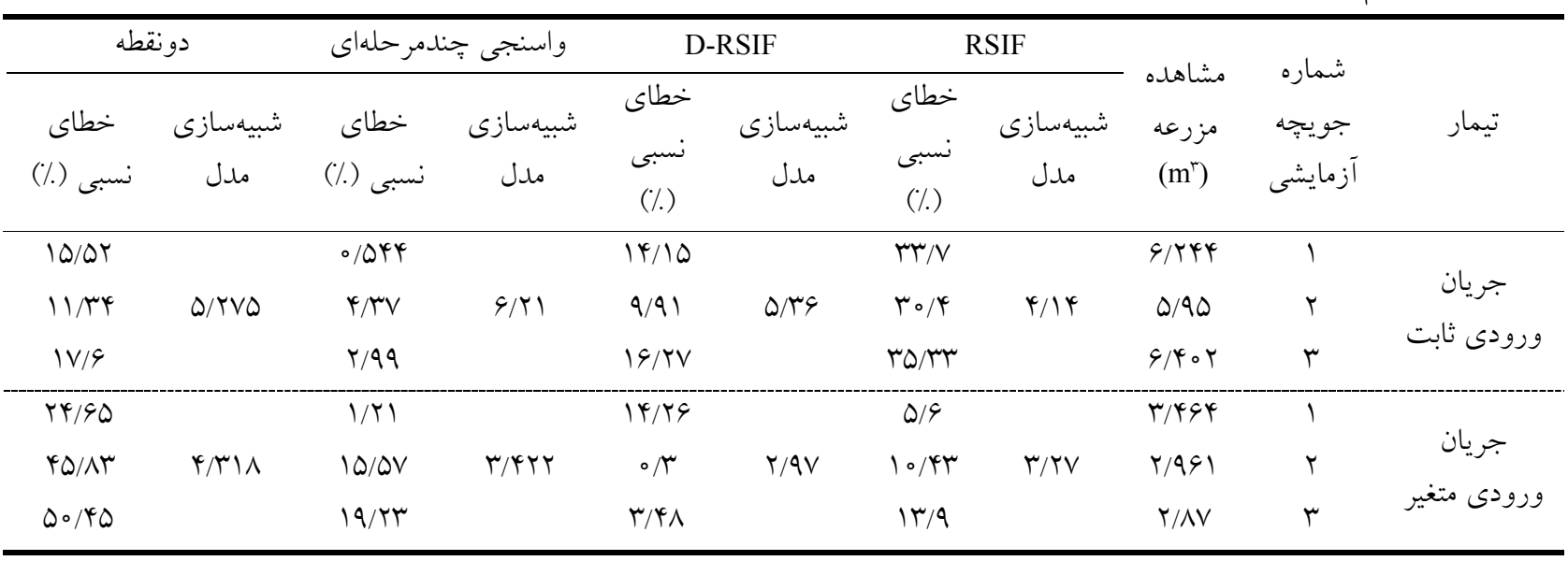

در شكل (ه) نمايى از هيدروكراف رواناب شبيهسازى شده توسـط است. در تيمـار جريـان ورودى متغيـر، روش D-RSIF نسـبت بـه

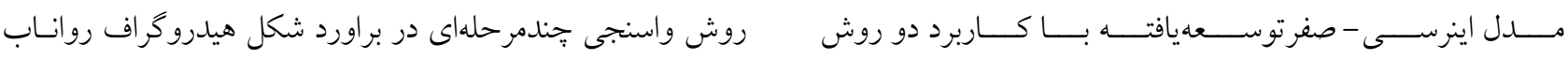

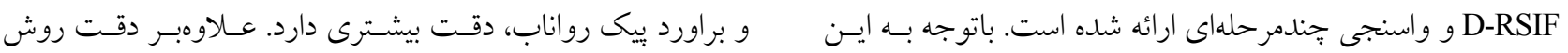
شكل تفاوت دو روش در سطح ينج درصد از نظر آمارى معنسدار D-RSIF بست به روش واسنجى جندمرحلهاى، ايسن روش سـاده 

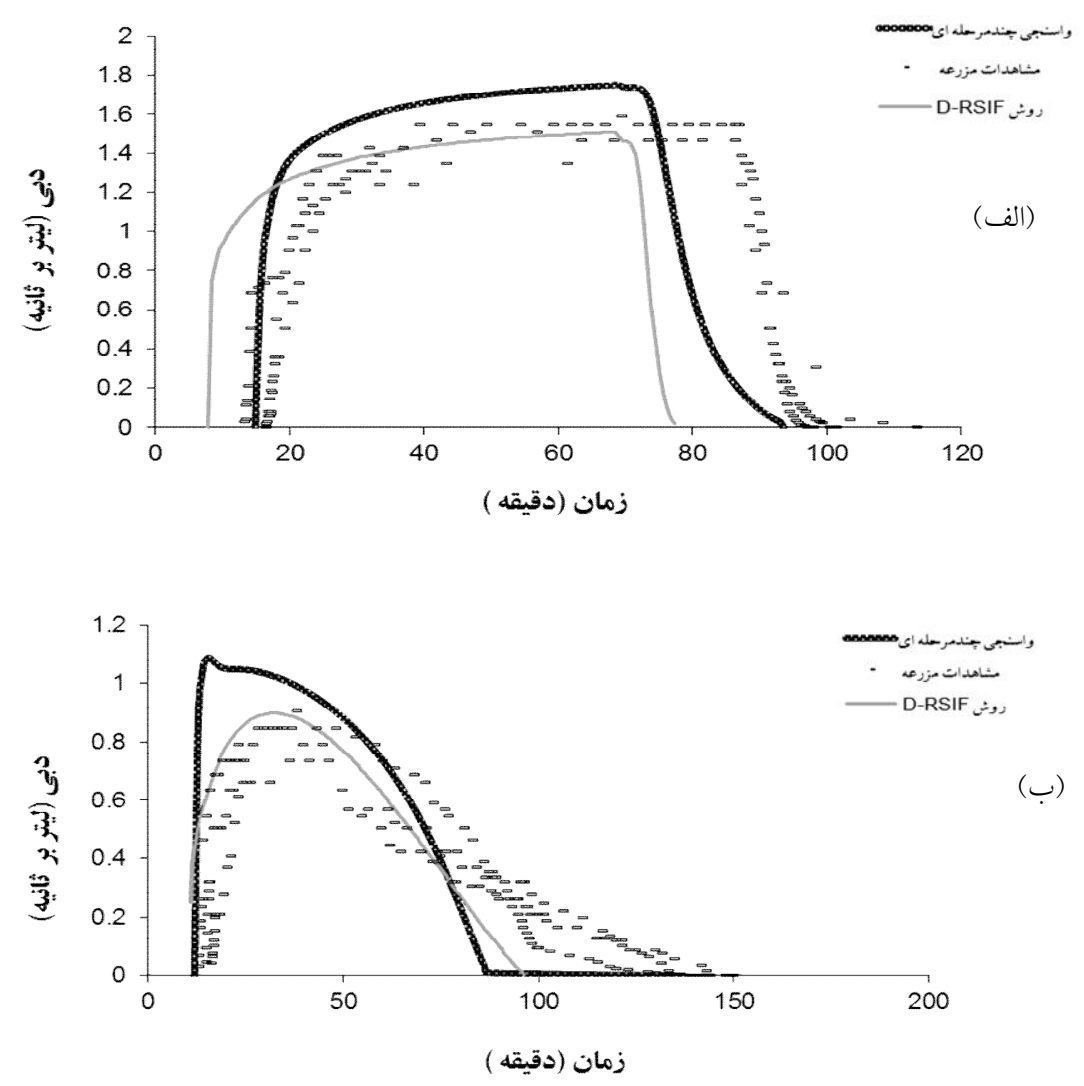

شكل ه. نمايى از مقايسه رواناب شبيهسازى شده با مدل اينرسى -صفر توسعه يافته با كاربرد دو روش D-RSIF و واسنجى جندمرحلهاى الف) جريان ثابت و ب) جريان متغير

آبيارى انجام مىشود. بهمنظـور بررسـى دقـت روش خـروه نفـوذ مبتنى بر اطلاعات خاى مزرعـه آزمايشسى، مــل اينرسىى - صـفر توسعهيافته براى تيمار جريان ورودىى متغير و باتوجه بـه ضـرايب

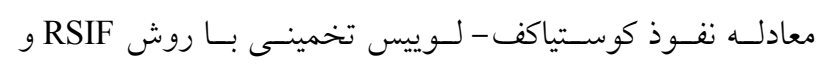
D-RSIF انتهاى جويجهة) اجرا شد. نتـايج شـبيهسـازى مـدل نشـان داد كـهـ

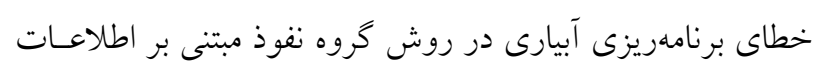

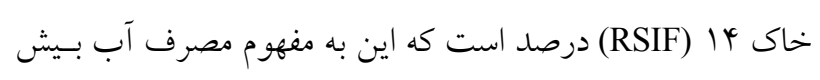
ازحد مورد نياز نسبت به برنامهريزى آبيارى با روش خـروه نفـوذ

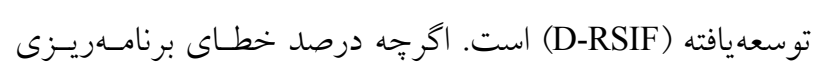

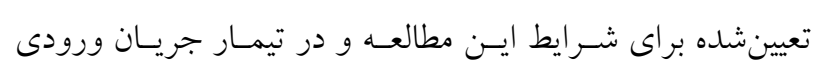
متغير ارائه شده است و نياز به بررسى بيشـتر در شـرايط متفــاوت

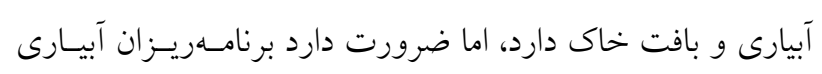

و سريع بوده و نياز به واسنجى با يكى تابع هـدف در يـك مرحلـه مبتنى بر حجـم روانـاب مشـاهده شـده و شسبيهسـازى شــده دارد.

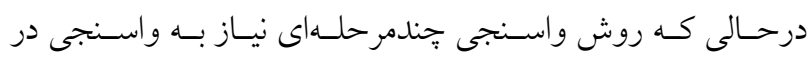
جهارمرحله با جهار تابع هدف دارد (YY).

\section{تتيجه كيرى}

روش كروه نفوذ توسعاهيافته برمبناى ويزگى هاى خـاك و شـرايط حاكم بر آبيارى (D-RSIF) در اين مطالعه ارائه شـــ. بـاتوجـهـ بـهـ نتايج اين مطالعه، دقت روش D-RSIF نسبت بـه روش RSIF در ارزيابى مراحل مختلف آبيارى، بيشتر است. توجـه بـه ايـن نكتـه

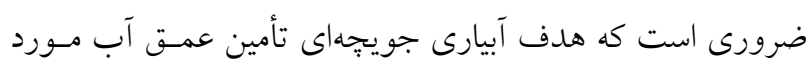
نياز كياه در انتهاى جويجه اسـت و برنامسهريسزى آبيـارى عمومـاً بهدليل محدوديت در تغيــرات حقابسه بـا اسـتفاده از تغييـر زمـان 


$$
\begin{aligned}
& \text { بهميزان خطاى برنامهريزى آبيارى با تكيه بـر ويزگگىهـاى خـاك سادكى نسبت به ساير روشهاى بهينهسازى مانند روش واسـنجى }
\end{aligned}
$$

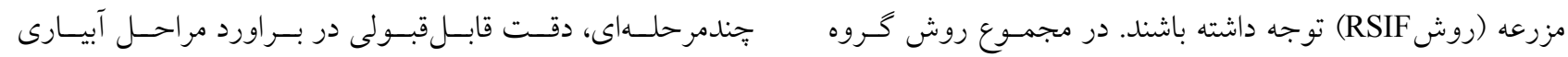

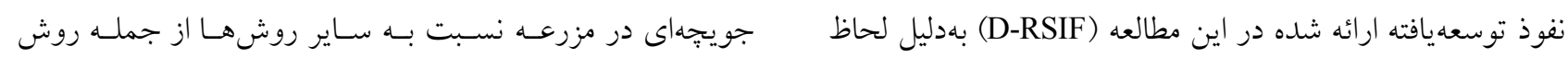

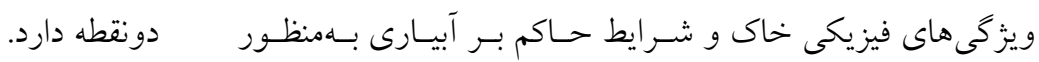

$$
\begin{aligned}
& \text { تخمين معادله نفوذ كوستياكف-لوييس بيشنهاد مىشود كه ضمن }
\end{aligned}
$$

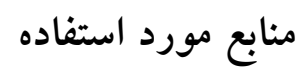

1. Bautista, E. and W. W. Wallender. 1993. Identification of furrow intake parameters from advance times and rates. Journal of Irrigation and Drainage (ASCE) 119(2): 295-311.

2. Bautista, E., A. W. Warrick, J. L. Schelegel, K. R. Thorp and D. J. Hunsaker. 2016. Approximate furrow infiltration model for time-variable ponding depth. Journal of Irrigation and Drainage Engineering 142(11): 1-11.

3. Behzad, M. and M. Mahmoodian Shooshtary. 1997.Effect of inflow rate on the furrow infiltration. In: Proceeding of the $2^{\text {nd }}$ Iranian Congress on Soil and Water Issues, Tehran. Pp: 15-28. (In Farsi).

4. Elliott, R. L. and W. R. Walker. 1982. Field evaluation of furrow infiltration and advance functions. Transactions of ASAE 25(2): 396400.

5. Elliott, R. L., W. R. Walker and G. V. Skogerboe. 1983. Infiltration parameters from furrow irrigation advance data. Transactions of ASAE 26(6): 1726-1731.

6. Fangmeier, D. D. and M. K. Ramsey. 1978. Intake characteristics of irrigation furrows. Transactions of ASAE 21(4): 696-705.

7. Gillies, M. H. and R. J. Smith. 2005. Infiltration parameters from surface irrigation advance and run-off data. Irrigation Science 24(1): 25-35.

8. Gillies, M. H., R. J. Smith and S. R. Raine. 2007. Accounting for temporal inflow variation in the inverse solution for infiltration in surface irrigation. Irrigation Science 25(1): 87-97.

9. Guardo, M., R. Oad and T. H. Podmore. 2000. Comparison of zero-inertia and volume balance advance-infiltration models. Journal of Hydraulic Engineering 126(6): 457-465.

10. Jurrie"ns, M. and K. J. Lenselink. 2001. Straightforward furrow irrigation can be $70 \%$ efficient. Journal of Irrigation and Drainage Engineering (ASCE) 50(3): 195-204.

11. Maroufpoor, E., A. Seyedzadeh, M. Behzadynasab. 2017. Investigation of the accuracy of non- point infiltration measurment methods in designing of furrow irrigation system. Journal of Water and Soil Conservation (Journal of Agricultural Sciences and Natural Resources) 24(3):257-2. (In Farsi).

12. McClymont, D. J. and R. J. Smith. 1996. Infiltration parameters from optimization on furrow irrigation advance data. Irrigation Science 17(1): 15-22.

13. Moravejalahkami, B., B. Mostafazadeh-Fard, M. Heidarpour and F. Abbasi. 2012. Comparison of multilevel calibration and volume balance method for estimating furrow infiltration. Journal of Irrigation and Drainage Engineering (ASCE) 138(8): 777-781.

14. Mostafazadeh-Fard. B. 1991. Determination of the kostiakov- lewis infiltration function parameters using volume balance equation for a furrow irrigation field at Isfahan. Agricultural Sciences and Technology Journal 5(1): 101-112.

15. Mostafazadeh, B. and W. R. Walker. 1981. Furrow geometry under surge and continuous flow. Iran Agricultural Research 6(2): 57-71.

16. Raine, S. R., D. J. McClymont and R. J. Smith. 1997. The development of guidelines for surface irrigation in areas with variable infiltration. Australian Society of Sugar Cane Technologists, Cairns, Australia 293-301.

17. Rastgoo, S. and S. Besharat. 2016. Evaluation and Comparison of the methods of estimating of Kostiakov-Lewis equation parameters in Furrow Irrigation. 2nd Iranian Natinal Congress of Irrigation and Drainage. Isfahan University of Technology: 8p. (In Farsi).

18. Renault, D. and W. W. Wallender. 1996. Initial-inflow-variation impacts on furrow irrigation evaluation. Journal of Irrigation and Drainage Engineering (ASCE) 122(1): 7-14.

19. Renault, D. and W. W. Wallender. 1997. Surface storage in furrow irrigation evaluation. Journal of Irrigation and Drainage Engineering (ASCE) 123(6): 415-422.

20. Scaloppi E. J., G. P. Merkley and L. S. Willardson. 1995. Intake parameters from advance and wetting phases of surface irrigation. Journal of Irrigation and Drainage Engineering (ASCE) 121(1): 57-70. 
21. Shaikh, I. F., A. Wayayok and M. A. Mangrio. 2017. Comparative Study of irrigation advance based infiltration methods for furrow irrigated soils. Pertanika Journal of Science and Technology 25(4): 1223 -1234.

22. Walker, W. R. and G. V. Skogerboe. 1987. Surface Irrigation: Theory and Practice. Prentice- Hall, Inc., Englewood Ciffs, New jersey.

23. Walker, W. R. 1989. Advantage and Disadvantage of Surface Irrigation: Guidelines for Designing and Evaluating Surface Irrigation Systems. Food and Agriculture Organization of the United Nations (FAO), Rome.

24. Walker, W. R. 2005. Multilevel calibration of furrow infiltration and roughness. Journal of Irrigation and Drainage Engineering (ASCE) 131(2): 129-136.

25. Walker, W. R., C. Prestwich and T. Spofford. 2006. Development of the revised USDA-NRCS intake families for surface irrigation. Agricultural Water Management 85: 157-164.

26. Yassin, M. A., A. A. Alazba and M. A. Mattar. 2016. A new predictive model for furrow irrigation infiltration using gene expression programming. Computers and Electronics in Agriculture 122 : 168-175.. 


\title{
The Investigation of the Estimation Precision of Infiltration Equation Parameters Based on Soil Physics Characteristics for Furrow Irrigation
}

\author{
B. Moravejalahkami ${ }^{1^{*}}$ \\ (Received: November 21-2018 ; Accepted: January 6-2019)
}

\begin{abstract}
Furrow irrigation is the most common method of surface irrigation. However, the accurate estimation of the soil water infiltration equation is the most important challenge for evaluating this method of irrigation. In this study, a fast and simple method that is named soil intake families and presented by USDA-NRCS (RSIF), evaluated for estimation of the Kostiakove-lewis infiltration equation parameters based on soil information. Also, this method was developed based on irrigation condition and considering soil characteristics (D-RSIF). Two treatments including constant and variable inflow discharge were tested with 4 repetitions and different irrigation phases including advance, storage and recession were simulated by developed Zero-Inertia model using RSIF and D-RSIF methods. The results showed that using the zero- inertial model, the difference between simulated advance times and simulated runoff were significant at $5 \%$ level for D-RSIF and RSIF methods. For variable inflow discharge, the error of estimating runoff volume was $10 \%, 6 \%, 12 \%$ and $41 \%$ for RSIF, D-RSIF, multilevel calibration and two-point methods respectively. Also, the irrigation scheduling error, based on soil physics characteristics (RSIF) was $14 \%$ that means consuming water more than required.
\end{abstract}

Keywords: Infiltration, soil physics characteristics, furrow irrigation, Zero-inertia model

1. Soil and Water Research Department, Yazd Agricultural and Natural Resources Research and Education Center, Agricultural Research, Education and Extension Organization (AREEO), Yazd, Iran.

*: Corresponding Author, Email: b.moravej@areeo.ac.ir 